\title{
Traditional Poultry Production and Commercial Production Opportunities in Kastamonu Province
}

\author{
Musa Sarıca $^{1, a}$, Nihat Akkalkan²,b, Kadir Erensoy ${ }^{1, c, *}$ \\ ${ }^{I}$ Ondokuz Mayls Üniversitesi, Ziraat Fakültesi, Zootekni Bölümü, 55139 Atakum, Samsun, Türkiye \\ ${ }^{2}$ Tarım ve Orman Bakanlığı Honaz Illçe Tarım ve Orman Müdürlüğ̈̈ 20330 Honaz, Denizli, Türkiye
}

*Corresponding author

\begin{tabular}{l|l}
\hline A R T I C L E I N F O & A B S T R A C T \\
\hline Research Article & $\begin{array}{l}\text { This study was carried out to reveal the structural traits and socio-economic contributions of poultry } \\
\text { production in Kastamonu province. In this research, the tendency of producers to switch to } \\
\text { commercial production and sustainability of production in existing commercial enterprises were } \\
\text { revealed. Due to the lack of broiler integration firms in Kastamonu, all broiler farms started egg } \\
\text { production over time. Egg production in commercial enterprises is marketed locally or to other } \\
\text { provinces. Structural traits of family or village poultry in the province show similarities with the } \\
\text { country. The vast majority of the producers stated that they do not consider the economic return in } \\
\text { production; they produce for family needs and hobby purposes. Producers stated that their products } \\
\text { are better quality than intensive production in terms of taste, odor and nutrients. However, in } \\
\text { traditional production, it has been revealed that chickens can reach all kinds of waste, detergent, } \\
\text { septic tank, oil waste, dirty water and diseases cause serious losses. It is stated that hens and roosters } \\
\text { accepted : } 15 / 06 / 2020 \\
\text { are together in production, chickens are produced from naturally produced eggs, and some chickens } \\
\text { are purchased. In addition, the fertility of eggs may lead to embryo development in the summer } \\
\text { depending on the storage conditions. This production has been shown to be effective for families to } \\
\text { access fresh eggs and meat. It is seen that there is not enough expectation for the development and } \\
\text { commercialization of the existing production system in the region. The production of other animal } \\
\text { Kastamonu, } \\
\text { Village poultry production, } \\
\text { Egg yield, } \\
\text { Commercial production trends seems more attractive. Especially avian diseases and the negative situation it causes are } \\
\text { Family poultry production } \\
\text { effective in producers not to prefer this area. In addition, it has been revealed that producers are not } \\
\text { willing to direct their capital savings to this area. }\end{array}$ \\
\hline
\end{tabular}

Tavukçuluk Araştırma Dergisi 17(1): 35-40, 2020

\section{Kastamonu İli Kanatı Hayvan Yetiștiriciliği ve Ticari Üretime Geçme İmkânları}

M A K A L E B İ L G I
Araştırma Makalesi
Geliş $\quad: 22 / 04 / 2020$
Kabul $\quad: 15 / 06 / 2020$

Anahtar Kelimeler:

Kastamonu

Köy tavukçuluğu

Yumurta verimi

Ticari üretim eğilimleri

Aile tavukçuluğu

\section{Ö Z}

$\mathrm{Bu}$ çalışma Kastamonu ilinde gerçekleştirilen kanatlı üretiminin yapısal özellikleri ile sosyoekonomik katkılarını ortaya koymak amacıyla yürütülmüştür. Araştırma ile ticari üretime geçme eğilimleri ve mevcut ticari işletmelerde üretimin sürdürülebilirliği ortaya koyulmuştur. Kastamonu'da etçi özellikte kurulan işletmelerin entegre bir şirket olmaması nedeniyle zaman içerisinde tamamı yumurta üretimine geçmiştir. Ticari işletmelerde yapılan yumurta üretimi yerelde veya diğer illere pazarlanmaktadır. İlde yapılan aile veya köy tavukçuluğunun yapısal özellikleri ülke geneli ile benzerlikler göstermektedir. Üreticilerin büyük çoğunluğu üretimde ekonomik getiriyi düşünmediklerini, aile ihtiyaçları ve hobi amaçlı üretim yaptıklarını belirtmişlerdir. Üreticiler ürünlerinin lezzet, koku ve besin açısından entansif üretime göre daha kaliteli olduğunu ifade etmişlerdir. Ancak, geleneksel üretimde tavukların her türlü atığa ulaşabildikleri (deterjan, fosseptik, petrol atıkları, kirli sulara vb.) ve hastalıkların ciddi kayıplara neden olduğu ortaya çıkmıştır. Üretimde tavuklarla horozların bir arada olduğu, üretilen yumurtalardan doğal kuluçka ile civciv üretildiği, bir miktar civciv, piliç veya tavuğun satın alındığı belirlenmiştir. Bu üretimin ailelerin taze yumurta ve tavuk etine ulaşmalarında etkili olduğu görülmüştür. Yörede mevcut üretim sisteminin gelişmesi ve ticarileşmesi için yeterli beklentinin olmadığ 1 görülmüştür. Diğer hayvansal ürünlerin üretimi daha cazip görünmektedir. Özellikle tavuk hastalıkları ve ortaya çıkardığı olumsuz durum üreticilerin bu alanı tercih etmemelerinde etkili olmaktadır. Bunun yanında üreticilerin sermaye birikimlerini bu alana yönlendirme konusunda da istekli olmadıkları ortaya çıkmıștır. 


\section{Giriş}

Günümüzde kanatlı hayvan yetiştiriciliği, özellikle de yumurta ve et tavukçuluğu önemli kapasite artışı ile en yoğun yapılan hayvansal üretim alanını oluşturmuştur (Nkukwana, 2018; Sarica ve ark., 2018; Sheldon, 2000; Waarst ve ark., 2015). Ülkemiz özellikle 1980'li yıllarda başlayan gelişmelerle son 30 yıl içerisinde ciddi kapasite artışları olmuş, et ve yumurta üretiminde dünyada en çok üretim yapan ilk 10 ülke içerisinde yer almıştır (Anonim a 2020; Anonim b., 2020 ). Tavuk ürünleri üretiminde giderek artış sağlayan Asya ülkelerinin gelecekte üretimlerini daha da arttırmaları beklenmekte, Türkiye bu üretim artışında önemli etkiye sahip ülkeler içerisinde yer almaktadır.

Ülkemizin hemen her bölgesinde kanatlı üretimi yapılmakla birlikte büyük tüketim merkezlerine yakın bölgelerle, teşvik yatırımlarının olduğu bazı illerde yumurta ve tavuk eti üretimi ciddi boyutlara ulaşmıştır. Etlik piliç üretiminde entegrasyonların da katkısıyla üretim belirli alanlarda daha fazla yoğunlaşmıştır (Aydın ve Çelen, 2017; Çimrin ve ark., 2019; Demirulus, 2001; Efil ve Sarıca., 1994; Köse ve Durmuş., 2014; Sarıca ve ark, 2018; Şahin ve Yıldırım, 2001). Bazı bölgelerde verilen teşvikleri değerlendirmek için yapılan yatırımlar civciv bulamama, kesimhane olmaması ve yumurta pazarlamasındaki güçlükler nedeniyle atıl kalabilmektedir (Sarıca ve ark., 2019). Ülkemizde tavuk eti ve yumurtanın tamamına yakını entansif üretimden sağlanmakla birlikte, geleneksel üretimden sağlanan kanatlı ürünlerine de değişik nedenlerle talep olmaktadır. Ülkemizde kırsal kesimde uygulama açısından çok büyük farklılıklar gösteren köy tavukçuluğu küçük kapasitesine rağmen, önemini korumaya devam etmektedir (Aksoy ve ark, 2007; Şekeroğlu ve Sarıca, 2010; Türkoğlu ve Eleroğlu, 1999). Buna rağmen "köy tavuğu" ürünlerinde tüketiciyi aldatmaya dönük uygulamalar bu ürünlere güveni azalttığ gibi, bu ürünleri doğal-organik gibi isimlendirmek te uygun değildir (Sarıca ve ark, 2018; Sarıca ve ark., 2018b ). Hayvansal üretimin geleneksel özellikleri ile yürütüldüğü bazı ülke ve bölgelerde çevre, iklim ve pazarlama gibi nedenlerle mevcut yapının korunması önem taşımaktadır (Jha ve Chakrabarti, 2017; Güngördü ve Çelen, 2018; Şekeroğlu ve Sarıca., 2010). Bu bölgelerde entansif üretime geçme çalışmaları da her zaman başarılı olamamaktadır. Bu nedenle kapsamlı verilerin derlendiği ve değerlendirildiği sonuçlara göre uygulamalar yapılması yararlı olacaktır. Bu çalışma Kastamonu ilinde gerçekleştirilen kanatlı üretiminin yapısal özellikleri ile sosyo-ekonomik katkılarını ortaya koymak amacıyla yürütülmüştür. Araştırma ile ticari üretime geçme eğilimleri ve mevcut ticari işletmelerde üretimin sürdürülebilirliği ortaya koyulmuştur. Yapılan çalışma geleceğe dönük yatırımlara fikir vermesi ve yol göstermesi açısından önemli görülmektedir.

\section{Materyal ve Yöntem}

Bu çalışma Kastamonu ilinde 2015 ve 2016 yıllarında yürütülmüştür. Kastamonu ili Batı Karadeniz bölgesinde $41^{\circ} 21^{1}$ kuzey enlemi ile $33^{\circ} 46^{1}$ doğu boylamları arasında yer alır. Rakımı $775 \mathrm{~m}$, yüzölçümü $13.136 \mathrm{~km}^{2}$ 'dir. Doğuda Sinop, güneyde Çankırı, kuzeybatıda Bartın, kuzeyde Karadeniz, batıda Karabük, güneydoğuda ise Çorum illeri ile çevrilidir. Kastamonu ili çoğunlukla engebeli arazilerden oluşmakta, ormanlık alanlar çoğunluğu oluşturmaktadır. 2020 yılı nüfusu 380.670 olup, nüfusun $\% 58,1$ ' $\mathrm{i}$ il ve ilçe merkezlerinde, $\% 41,9$ 'u ise belde ve köylerde yaşamaktadır. Ekonomisi geniş oranda tarıma dayalı olan ilde kanatlı hayvan üretimine ait birkaç işletme dışında ticari işletme bulunmamaktadır.

Çalışma Kastamonu Merkez ve İlçelerindeki nüfus yoğunluğu ve kanatlı hayvan varlığ 1 dikkate alınarak rastgele seçilen 280 üretici ile yüz yüze anket yöntemiyle alınan verilere dayandırılmıştır. Çalışma yapıldığı dönemdeki ismi ile Kastamonu Gıda Tarım ve Hayvancılık İl Müdürlüğü çalışma alanına girmektedir. Kurumda Tarımsal Yayım hizmetlerinde görevli Ziraat Mühendisi olan Yüksek Lisans öğrencisi vasitasıyla mesleki görevleri sonucu elde edilen verilerin önemli bir kısmı bu tezde değerlendirilmiştir. Tezin yürütülmesi; Kastamonu Valiliği İl Gıda, tarım ve Hayvancılık Müdürlüğünün 24 Nisan 2015 tarih ve 88019245/325-05-01. 624-4118 say1l yazılı izinleri ile gerçekleştirilmiştir.

Araştırmanın başlangıcında Kastamonu ilinde resmi kayıtlarda yer alan kanatlı hayvan sayıları dikkate alınarak il merkezi ve ilçelerde yapılacak anket sayıları belirlenmiştir. Kastamonu ilinde 2014 yılı resmi kayıtlara göre kanatlı hayvan sayıları dikkate alınarak anket sayıları belirlenmiştir (Çizelge 1)

Anket uygulanacak aile işletmeleri bu hayvan varlığına göre (1000 hayvan birimi için 1 aile işletmesi) belirlenmiş, kesirli rakamlar bir üst düzeye çıkarılmıştır. Bu konuda Tarım ve Orman İl Müdürlüğü'nün istatistik anketlerinde uyguladığı yöntemler dikkate alınarak geçekleştirilmiştir. Zira bu çalışma aynı zamanda detaylı verilerin ilgili kamu kuruluşu için envanter olarak kullanılması da amaçlanmıştır. Çalışma 2015-2016 yıllarında (TemmuzNisan) gerçekleştirilmiştir. Sonuçlara ait tanımlayıcı değerler ortalamalar, frekanslar, minimum ve maksimum değerlerle ifade edilmiştir.

\section{Bulgular}

\section{İşletme Sahibi İle İlgili Bilgiler}

Kastamonu il merkezi ile 19 ilçesinde yapılan rastgele seçilen 280 üreticinin anket sonucuna göre kanatlı hayvan sahibi olan aile işletmelerinde işletme sahiplerinin yaş ortalamasi 53 (25-85 arasinda), bizzat hayvanlarla ilgilenenlerin yaş ortalaması ise 51 (25-85 arasında) belirlenmiştir. İşletme sahiplerinin \%50,7'si ilkokul mezunu iken, \%33,6'sı ortaokul, \%13,6'sı lise, \%4,0'ü ön lisans ve \%1,8'inin lisans mezunu oldukları tespit edilmiştir. Lisans mezunlarının Çatalzeytin, Azdavay ve Seydiler ilçelerinde yoğunlaştığı görülmüştür. İşletmelerde hayvanlara bakanların \%67,4'ü ev hanımları iken, $\% 23,3$ 'ü aile reisi, $\% 8,2$ 'si yaşlı ebeveynler, $\% 1,1$ 'i ise çocuklardan oluşmuştur.

Ankete katılan işletmelerin $\% 96,1^{\prime} \mathrm{i}$ büyükbaş hayvancılık, \%35,9'u ise küçükbaş hayvancılık yapmaktadır. Yine aynı işletmelerin $\% 76,8^{\prime} \mathrm{i}$ tarla bitkileri ve sebze üretimi yapmaktadır. Meyve bahçesi bulunan işletmelerin oranı \%79,9'dur. İşletme sahiplerinin yalnız $\% 1,1$ 'i kanatlı hayvan yetiştiriciliği dışında bir üretim yapmamaktadır. 
Çizelge 1. Kastamonu ilinde kanatlı hayvan varlığı ve çalışmada kullanılan anket sayıları

\begin{tabular}{|c|c|c|c|c|c|c|c|}
\hline \multirow{2}{*}{ İlçe } & \multicolumn{6}{|c|}{ Kanatlı hayvan varlığı (adet) } & \multirow{2}{*}{$\mathrm{UAS}^{* * *}$} \\
\hline & Tavuk & Hindi & Ördek & $\mathrm{Kaz}$ & Güvercin & $\mathrm{DK}^{*}$ & \\
\hline Abana & 760 & 5 & 3 & 4 & 5 & 0 & 8 \\
\hline A $\breve{g l} l_{1}$ & 4.020 & 1.150 & 306 & 95 & 0 & 0 & 5 \\
\hline Araç & 21.960 & 2.500 & 1.159 & 433 & 21 & 29 & 22 \\
\hline Azdavay & 8.760 & 450 & 0 & 0 & 0 & 0 & 9 \\
\hline Bozkurt & 1.360 & 90 & 6 & 8 & 0 & 0 & 4 \\
\hline Cide & 15.400 & 1.050 & 149 & 27 & 32 & 17 & 16 \\
\hline Çatalzeytin & 6.180 & 10 & 37 & 7 & 0 & 115 & 8 \\
\hline Daday & 9.510 & 555 & 131 & 53 & 17 & 0 & 10 \\
\hline Devrekâni & 15.537 & 1.111 & 59 & 378 & 0 & 0 & 16 \\
\hline Doğanyurt & 4.522 & 15 & 53 & 17 & 0 & 0 & 6 \\
\hline Hanönü & 4.473 & 60 & 0 & 44 & 23 & 0 & 6 \\
\hline İhsangazi & 9.552 & 514 & 188 & 156 & 0 & 0 & 10 \\
\hline İnebolu & 8.498 & 95 & 74 & 8 & 9 & 5 & 10 \\
\hline Küre & 3.265 & 98 & 44 & 34 & 0 & 0 & 4 \\
\hline Pınarbaşı & 4.548 & 170 & 49 & 16 & 0 & 0 & 6 \\
\hline Seydiler & 6.331 & 800 & 1.157 & 46 & 0 & 0 & 8 \\
\hline Şenpazar & 6.222 & 32 & 118 & 47 & 67 & 0 & 8 \\
\hline Taşköprü & 31.518 & 5.710 & 52 & 418 & 7 & 314 & 32 \\
\hline Tosya & 22.050 & 570 & 116 & 420 & 33 & 0 & 22 \\
\hline Merkez & 67.215 & 5.100 & 1.065 & 1.375 & 210 & 0 & 70 \\
\hline Toplam & 251.681 & 20.085 & 4.766 & 3586 & 424 & 480 & 280 \\
\hline
\end{tabular}

"DK: Diğer kanatlılar; ${ }^{* *}$ UAS: Uygulanan anket sayısı, Kaynak: Gıda Tarım ve Hayvancılık Bakanlığı, Kastamonu İl Müdürlüğü, 2014).

\section{İsletmelerle İlgili Bilgiler}

Aile işletmelerinde bulunan tavukların 5 ile 112 adet arasında değişim gösterdiği ve işletme başına ortalama 22 tavuğun bulunduğu belirlenmiştir. İlde kaz, ördek, hindi, bıldırcın ve diğer kanatlıların üretim düzeyi oldukça sınırlı bulunmuştur. İşletmelerin yetiştirdikleri tavukların \%56,4'ünün doğal kuluçkadan, \%17,9'unun pazarlardan piliç veya tavuk olarak, \%17,5'inin pazardan veya doğal kuluçka ile civciv olarak, \%8,2'sinin ise pazardan civciv şeklinde temin ettikleri belirlenmiştir. Aile işletmelerinin \%92,3'ünde tavukların diğer hayvanlarla birlikte barındırıldığı ve \% 7,7'sinde ise ayrı barınakta tutulduğu tespit edilmiştir. Kastamonu ilinde aile işletmelerinde yılda üretilen veya alınan civciv-piliç veya tavuk sayıları sırasıyla ortalama olarak 7 (0-60), $4(0-46)$ ve $4(0-40)$ adet belirlenmiştir. İşletmelerde üretilen y1llık yumurta verimi ortalama 1500 (340-6000) adet, tavuk başına yumurta veriminin ise ortalama $100(12-257)$ adet olduğu tespit edilmiştir. Üretilen yumurtaların \%55,4'ünün aile içinde tüketildiği, \%44,6'sında bir kısmının tüketildiği bir kısmının pazarlandığı belirlenmiştir. Yumurtaların \%97,6'sının pazarlarda, \%2,4'ünün ise bakkal veya diğer şekillerde pazarlandığı tespit edilmiştir.

Yumurtaların depolama sürelerinin 3,5-4,0 gün olduğu, pazara verilme sıklığının ise haftada 1 gün olduğu belirlenmiştir. İşletmelerin tamamında tavukların horozlarla bir arada yetiştirildiği, \%80,3'ünde horozların her yıl aynı sayıda tutulduğu, \%19,7'sinde ise sayılarda değişme olduğu, genellikle 3-4 tavuk için 1 horoz bulundurulduğu, yıl içinde kesilen horozlarla bu sayının 7-8 tavuk için 1 horoza kadar düştüğü belirlenmiştir. İşletmelerde ölen hayvanların önemli bir k1smının gömüldüğü $(\% 43,6)$, kedi-köpek gibi hayvanlara verildiği $(\% 3,9)$ veya yakıldığ $(\% 1,8)$ belirlenmiş, bazı işletmelerde ise bu yöntemlerin karışık olarak uygulandığı $(\% 50,7)$ tespit edilmiştir. Karışık işlemlerden en çok kullanılanlar ise gömme ve yakma
$(\% 10,0)$ atma ve hayvanlara verme $(\% 5,4)$ olarak belirlenmiştir. İşletmelerin \%98,9'unda hiç aşılama yapılmadı ̆̆ $1, \% 1,1$ 'inde ise Newcastle hastalığına karş1 aşılama yapıldığ kanatlılara \%99,6 oranında ilave yem verildiği belirlenmiştir. Verilen yemlerin önemli bir kısmının tahıllar, ev atıkları ve fabrika yemleri oluştururken $(\% 62,5)$ tahil-fabrika yemleri ikinci sırada $(\% 23,2)$ ev atıkları ve tahıllar üçüncü sırada $(\% 11,1)$ yer almıştır. Yalnız fabrika yemi kullanımı hiçbir işletmede uygulanmamaktadır. Tahılların ise \%52,9'unu buğdayarpa karışımı, \%23,6'sını buğday-arpa-mısır karışımı, $\% 12,5$ 'ini arpa, \%8,8'ini buğday oluşturmuştur. Arpamisır $(\% 2,5)$ buğday-mısır $(\% 0,7)$ karışımları daha az kullanılmaktadır. İşletmelerde tavuklara büyük oranda su verildiği $(\% 69,6)$ bazı işletmelerde ise dış ortamda aldıkları su ile yetinildiği $(\% 30,4)$ belirlenmiştir. Su verilen işletmelerde değişik kaplar $(\% 61,9)$ oluklar $(\% 20,5)$ suluklar $(\% 8,3)$ yalaklar $(\% 5,4)$ veya karışık uygulamalar yapılmaktadır.

İşletmelerde bulunan tavukların \%50,0'sinin evin bulunduğu bahçede, \%26,8'inin bahçe ve evin etrafinda, $\% 11,1$ 'inin evin etrafinda gezindikleri, \%12,1'nin ise orman dâhil üç seçenek karışımı yerlere ulaşabildikleri belirlenmiştir. Tavukların \%78,9'unun hayvan gübrelerine, \%14,0'ünde gübre ve diğer atıklara, $\% 5,0$ 'inde gübre ve deterjan atıklarına, $\% 2,2$ 'sinde ise gübre ve tuvalet fosseptiklerine ulaşılabildiği tespit edilmiştir.

İşletmelerden \%82,8'inde hayvan satışı yapılmadığı, satış yapan işletmelerin \%17,2 düzeyinde olduğu; bunlarda da satışların ihtiyaç duyuldukça gerçekleştiği ifade edilmiştir. Üreticilerin piliç eti üzerindeki olumsuz algısı ve köy tavuklarını tercih etme durumlarında en önemli etkenin lezzet $(\% 77,9)$ olduğu belirlenmiştir. Lezzet konusunda 
özellikle yağlılık, renk ve çiğnene bilirliğin en önemli etken olduğu tespit edilmiştir. Bunu sağlıklılık $(\% 27,9)$ ve doğal olma $(\% 24,3)$ gibi seçenekler izlemiştir. Tüketici tercihlerini etkileyen diğer konuları ise, koku $(\% 13,6)$ tat $(\% 12,9)$, renk $(\% 10,7)$ güvenilirlik $(\% 8,9)$ ve yağlılık $(\% 6,8)$ izlemiştir. Diğer yandan doğal olma $(\% 24,3)$ ile organik $(\% 5,4)$ seçeneklerinin yanlış algıdan kaynaklandığı, üreticilerin büyük oranda organik üretim şartlarını bilmedikleri $(\% 92,6)$ tespit edilmiştir. Üreticilere ticari et ve yumurta tavukçuluğu yapar mısınız sorusuna
\%90,6 hayır cevabı alınmıştır. Hayır, cevabı verenlerin sebep olarak \%26,1'i ekonomik durumlarının yetersizliğini, \%20,7'si yaşlarının uygun olmadığını, \%12,1'i zamanlarının olmadığını, \%9,7 üretimin zor olduğunu, \%5,7'si üretimin yeterince karlı olmadığını, \%2,9'u sağlık sorunlarının yüksek olduğunu, $\% 1,1$ ' $\mathrm{i}$ ise riskli olduğunu belirtmişlerdir. Üreticilerden \%21,7'lik grup ise birden fazla nedenle üretim yapamayacaklarını, ancak burada en etkin sebebin ekonomik durumdan kaynaklandığı belirtmişlerdir. (Çizelge 2).

Çizelge 2. Ticari tavukçuluk üretimi konusunda üreticilerin eğilimleri

\begin{tabular}{l|ccccccccccccc}
\multicolumn{1}{c}{ İlçeler } & 1 & 2 & 3 & 4 & 5 & 6 & 7 & 8 & 9 & 10 & 11 & 12 & 13 \\
\hline Abana & 12,5 & 0 & 37,5 & 12,5 & 25,0 & 12,5 & 0 & 0 & 0 & 12,5 & 0 & 0 & 0 \\
Ağlı & 0 & 0 & 20,0 & 0 & 20,0 & 0 & 0 & 0 & 20,0 & 0 & 20,0 & 0 & 20,0 \\
Araç & 13,6 & 4,5 & 18,2 & 13,6 & 22,7 & 9,1 & 9,1 & 0 & 4,5 & 13,6 & 4,5 & 0 & 0 \\
Azdavay & 0 & 0 & 0 & 44,4 & 22,2 & 0 & 11,1 & 0 & 0 & 22,2 & 0 & 0 & 0 \\
Bozkurt & 0 & 0 & 25,0 & 25,0 & 50,0 & 0 & 0 & 0 & 0 & 0 & 0 & 0 & 0 \\
Cide & 0 & 0 & 56,2 & 12,5 & 6,2 & 0 & 0 & 0 & 0 & 0 & 31,2 & 0 & 25,0 \\
Çatalzeytin & 0 & 0 & 12,5 & 0 & 0 & 25,0 & 12,5 & 12,5 & 12,5 & 0 & 0 & 0 & 0 \\
Daday & 0 & 0 & 10,0 & 10,0 & 40,0 & 10,0 & 10,0 & 0 & 0 & 0 & 10,0 & 0 & 0 \\
Devrekani & 6,2 & 0 & 50,0 & 0 & 12,5 & 6,2 & 18,8 & 0 & 0 & 12,5 & 0 & 6,2 & 0 \\
Doğanyurt & 0 & 0 & 83,3 & 0 & 50,0 & 0 & 0 & 0 & 0 & 50 & 0 & 0 & 0 \\
Hanönü & 0 & 0 & 50,0 & 16,7 & 66,7 & 0 & 0 & 0 & 0 & 0 & 0 & 0 & 0 \\
İhsangazi & 10,0 & 20,0 & 10,0 & 30,0 & 30,0 & 0 & 0 & 0 & 0 & 0 & 0 & 0 & 0 \\
İnebolu & 10,0 & 0 & 10,0 & 20,0 & 0 & 20,0 & 10,0 & 0 & 0 & 10,0 & 20,0 & 0 & 0 \\
Küre & 0 & 0 & 25,0 & 0 & 25,0 & 0 & 0 & 0 & 0 & 50 & 0 & 0 & 0 \\
Pinarbaş1 & 16,7 & 0 & 33,3 & 33,3 & 33,3 & 0 & 0 & 0 & 0 & 0 & 0 & 0 & 0 \\
Seydiler & 0 & 12,5 & 25,0 & 0 & 0 & 12,5 & 25,0 & 0 & 12,5 & 0 & 12,5 & 0 & 25,0 \\
Şenpazar & 0 & 0 & 12,5 & 12,5 & 12,5 & 0 & 25,0 & 0 & 0 & 12,5 & 12,5 & 0 & 0 \\
Taşköprü & 9,4 & 0 & 15,6 & 3,1 & 15,6 & 6,2 & 6,2 & 12,5 & 0 & 40,6 & 6,2 & 6,2 & 0 \\
Tosya & 4,5 & 0 & 18,2 & 13,6 & 31,8 & 18,2 & 4,5 & 0 & 0 & 4,5 & 0 & 0 & 0 \\
Merkez & 4,3 & 0 & 28,6 & 10,0 & 18,6 & 4,3 & 7,1 & 0 & 5,7 & 7,1 & 2,9 & 0 & 1,4 \\
Toplam & 5,4 & 1,4 & 26,1 & 11,4 & 20,7 & 6,8 & 7,5 & 1,8 & 2,9 & 12,1 & 5,7 & 1,1 & 2,9 \\
\hline
\end{tabular}

1:Büyükbaş hayvancılıkla uğraştığım için zamanım yok; 2:Tavukçulukta ihtiyacımdan fazlasını istemiyorum; 3:Ekonomik durumum uygun değil; 4:Düşünmüyorum; 5:Yaşım uygun değil; 6:Uğraşmak istemiyorum; 7:İhtiyacım yok; 8:Yer sıkıntıs1 var; 9:Riskli; 10:Zamanım yok; 11:Karlı değil; 12:Sağlık sorunları yüksek; 13:Ticari üretim zor

\section{Tartışma ve Sonuç}

Sivas yöresinde yapılan çalışmada kadınların tavuklarla ilgilenme oranları $\% 65$, erkeklerin $\% 14,9$ ve çocukların $\% 2,1$ olduğu belirtilmiş ve bulgularımızla benzer bulunmuştur (Eleroğlu ve ark., 2014). Diğer bir çalışmada ise Bingöl ilinde kırsal kesimde yetiştiricilerin \%75,7'sinin erkeklerden oluştuğu, yetiştiricilerin yaş ortalamasının 45,2 eğitim durumlarının ise okuma-yazma bilmeyen ve ilkokul mezunlarının ağırlıklı olduğu (\%69,2+ \%26,3) belirtilmiştir (İnci ve ark., 2015). Çalışmamızda Bingöl ilinde göre erkeklerin hayvanlarla ilgilenme düzeyinin daha düşük $(\% 23,3)$ olduğu, yetiştiricilerin yaş ortalamasının ise daha yüksek olduğu belirlenmiştir. Bu duruma bölgesel ve sosyoekonomik bazı faktörlerin etkisinin olduğu düşünülmektedir. Bingöl'deki durumun aksine Türkiye'nin genelinde ev kadınları ve yaşlı aile işgücü küçük çaplı kanatlı üretiminde $\% 90$ düzeyinde etkili olmakta, tüm bakım işlemleri bunlar tarafindan yürütülmektedir (Güngördü ve Çelen, 2018). Çalışmamızda da kanatlı hayvanların bakım işlerinde ev hanımları-kadınlar ön plana çıkmıştır. Dünya'da değişik bölgelerde yapılan çalışmalarda da ev kadınlarının tüm bakım işlerinden sorumlu olduğu bildirilmiştir (Rimi ve ark., 2016). Bingöl ilinde geleneksel üretim amaçlı tavukçuluğun ön planda olup bundan ekonomik getiri beklenme oranı yüksektir (İnci ve ark., 2015). Batman ilinde de aile işletmelerinin ana gelir kaynağını tarla bitkileri $(\% 52,6)$, büyük ve küçükbaş hayvancılık $(\% 27,8)$ oluşturmakta, tavukçuluğun doğrudan gelir kaynağ olmadığ1 belirtilmiştir (Güngördü ve Çelen, 2018). Diyarbakır ilinde köy tavukçuluğunun sürdürülmesinde gelirden ziyade geleneksel yapının etkili olduğu $(\% 97,0)$ belirlenmiştir (İnci ve ark., 2018). Çalışmamızda da Kastamonu ili için tavukçuluğun ana gelir kaynağı olmadığı, sırasıyla büyükbaş hayvancılık, tarla bitkileri, meyve ve sebze üretiminin aile ekonomisinde daha fazla pay sahibi olduğu tespit edilmiştir.

Kırsal kesimde geleneksel köy tavukçuluğunda kapasitenin aile başına 1-10 tavuk olmasına rağmen, kısmen gelişmiş üretim sistemlerinde 10-50, yarı entansif köy tavukçuluğunda ise 50-200 adet arasında olmaktadır (Şekeroğlu ve Sarıca, 2010). Batman ilinde 6-10 kapasite aralığında yumurta ve et üretim amaçlı küçük aile işletmelerinin daha fazla olduğu, üreticilerin \%68'inin civcivlerini doğal kuluçka ile \%11,27'sinin ise satın aldıkları belirtilmiştir (Güngördü ve Çelen, 2018). Çalışmamızda ise kapasite olarak işletme başına düşen tavuk sayısı 5-112 adet ile Batman ilinden yüksek bulunmuştur. Batman'dakilere göre civcivlerini daha az pazardan alan Kastamonu'daki üreticilerin civciv teminini \%56.4 oranında doğal kuluçka ile 
elde ettiği tespit edilmiştir. Geleneksel yöntemle yapılan köy tavukçuluğunda hayvanlara \%95,5 oranda kapalı barınak imkânı sağlanması (İnci ve ark., 2015), çalışmamız sonuçları ile benzer bulunmuştur. Kırsal kesimdeki tavukçuluğun yapısal özelliklerinin farklı olmasına rağmen \% 75,2 düzeyinde ayrı kümeslerde (genellikle alçak basit kapalı barınak) barındırma yapılmaktadır (Eleroğlu ve ark., 2014). Ancak çalışmamızda tavukların ayrı barınaklarda barındırıldığ 1 işletmelerin oranı \%7,7 olarak düşük düzeyde kalmıştır.

Aile işletmelerinde tavuk başına yıllık yumurta verimi 100-150 adet arasında gerçekleşmektedir (Güngördü ve Çelen, 2018). Çalışmamızda da işletmelerin benzer düzeyde yumurta verimi (100 adet) elde ettikleri belirlenmiştir. Sivas yöresinde köy tavuklarında yıllık yumurta veriminin 80,92 adet olduğu bildirilmekte (Eleroğlu ve ark., 2014) ve çalışmamızda tespit edilen yumurta veriminden düşük olarak gerçekleşmiştir. Üretimin ticari amaçlar gözetilerek gerçekleştirildiği bazı ülkelerde üretimin küçük kapasiteli sürülerle ancak tavukların istedikleri her yerde gezinmelerini de engelleyen bahçe tavukçuluğu şeklinde yapıldığı tanımlanmıştır (Waarst ve ark., 2015). Divyan Red tavuklarının yetiştirildiği Hindistan'a ait bir bölgede bahçe tip tavukçuluğa ait 10 işletmenin verilerini değerlendirilmiş, yıllık yumurta veriminin tavuk başına 210 adet olduğunu belirtilmiştir (İnci ve ark., 2017).

Çalışmamızda ise yumurta verimlerinin daha düşük olduğu tespit edilmiştir (İnci ve ark., 2017). Diğer çalışmalar ile çalışmamız arasında yumurta verimi bakımından büyük varyasyonlar bulunmaktadır. $\mathrm{Bu}$ duruma hayvanların genetik yapısı, barındırıldığı çevre koşulları, beslenme düzeyleri ve yetiştirme sistemlerindeki farklılıkların neden olduğu düşünülmektedir (Sarıca ve ark., 2018b ).

Yapılan çoğu çalışmada kırsal alanda küçük kapasite ile yapılan tavukçulukta ana ürünün yumurta olduğu ve bunun önemli bir kısmının aile içerisinde tüketildiği, ancak pazara arz edilen kısmın aile için bir destek olarak görüldüğü belirtilmektedir (Şekeroğlu ve Akşimşek, 2009). Üreticilerin \%89,7'sinin üretimden elde edilen yumurta ve diğer ürünleri satmadıklarını, \%10,3'ünün ise satış yapma eğiliminde olduğunu belirtilmiştir (Güngördü ve Çelen, 2018). Uzakdoğu ve bazı Asya ülkelerinde küçük kapasiteli aile işletmeleri hane halkının yumurta ve tavuk eti ihtiyacını karşılayan önemli bir üretim kaynağıdır (Fajemilehin, 2010; Jha ve Chakrabarti, 2017; Waarst ve ark., 2015). Çalışmamızda da üretilen yumurtaların yarısından fazlasının satılmadığı, ailelerin kendi ihtiyaçları için kullanıldı ̆̆ belirlenmiştir.

Üreticilerin horozlar ile tavuklarını bir arada bulundurması döllü yumurta üretimine neden olmaktadır. Özellikle sıcak yaz aylarında uygun olmayan depolama koşulları nedeniyle döllü yumurtalarda embriyo gelişmesi bu yumurtaların tüketim amaçlı değerlendirilmesinde sorunlar yaşanmasına neden olmaktadır (Sarıca ve ark., 2018b).

Sürü sağlığı ve aşılama uygulamaları ile ilgili olarak, Tokat yöresinde ticari işletmeler dışındaki geleneksel üretimde sağlık koruma önlemlerine dikkate edilmediğini, salgın hastalıklara karşı herhangi bir aşılama yapılmadığını, bazı üreticilerin kireç kullanarak veya içme suyu ile aspirin vb. ilaçları vererek tedavi yapmaya çalıştıkları belirtilmiştir (Şekeroğlu ve Akşimşek., 2009).
Çalışmamızda da aşılama uygulamalarından çok düşük düzeyde yararlanıldığı belirlenmiş, hastalık etkenleri bakımından üretimin sürdürülebilirliğinin zor olduğu sonucuna varılmıştır. Üretimde aşı ve ilaç kullanımının yeterli olmadığı $(\% 60,9)$, hastalık çıktığında sürünün tamamına yakınının öldüğü $(\% 53,2)$ dolayısıyla kırsal kesimde tavuk üretiminin giderek azaldığ1 belirtilmiştir (Güngördü ve Çelen, 2018; İnci ve ark., 2015). Diyarbakır ilinde de üreticilerin tavukçuluğu sürdürememelerinde en büyük etkenin hastalıklar olduğu ortaya çıkmıştır (İnci ve ark., 2018). Kırsal kesimde önemli bir kaynak olan tavukçulukta son yıllarda görülen kuş gribi nedeniyle, üretim ve ürün tüketiminde ciddi farklılaşmalar olduğu bildirilmiştir (Rimi ve ark., 2016).

Bitkisel üretimdeki etkinliği nedeniyle Sivas yöresinde köy tavuklarına \%89,8 oranında buğday verilmektedir (Eleroğlu ve ark., 2014). Yine aynı araştırmada, yemlerin büyük oranda bir yemlikle verilmediği $(\% 61,4)$ belirtilmiştir. Bingöl'de tavukların beslenmesinde ev-mutfak-arazi artıkları \%91,0 oranında kullanılırken, otlatma $\% 59$, dane yem kullanımı $\% 28,2$, fabrika yemlerinin ise $\% 1,3$ düzeyinde kullanıldığ 1 ifade edilmiştir (İnci ve ark., 2015). Benzer besleme eğilimleri değişik bölgelerde kırsal kesimde yürütülen diğer çalışmalarda da ortaya çıkmaktadır (Güngördü ve Çelen, 2018; İnci ve ark., 2018).

Çalışmamızda da ilave yemleme için büyük oranda tahıllar, ev atıkları ve fabrika yemlerinin kullanıldığı belirlenmiş, ancak tahılların kullanımı bölgesel ürün farklılıklarından dolayı farklılık göstermiştir. Suluk kullanımında da basit kaplardan yuvarlak suluklara kadar farklılıklar bulunmaktadır. Suluk kullanım oranı çalışmamızla benzer düzeyde $\% 64,7$ bulunmuştur (Eleroğlu ve ark., 2014).

Kontrolsüz bir şekilde dış ortamda gezen tavuklar tüm etkenlere açık olduğundan herhangi bir zararlı maddenin tüketimi kolaylaşmakta ve ürünlerinde kalıntıya neden olabilmektedir (Şekeroğlu ve ark., 2013). Sivas yöresinde de köy tavuklarından elde edilen yumurtaların \%43,24'ünün evde tüketildiği, \%23,20'sinin hediye olarak başkalarına verildiği ve \%33,57'sinin ise pazara arz edildiği belirtilmiştir (Eleroğlu ve ark., 2014). Bu bakımdan kontrolsüz yapılan üretim insan sağlığı için risk teşkil etmektedir. Hayvanlar büyük oranda olumsuz atıklara ulaşabilmelerine rağmen yetiştirme şekli doğal veya organik olarak kabul edilmektedir.

Kastamonu ilinde ticari et ve yumurta tavukçuluğunun başta ekonomik olmak üzere birden fazla sebepten dolayı yapılmasının zor olduğu belirlenmiştir. Benzer eğilimler diğer araştırmacılar tarafindan da belirlenmiş olup, köy tavukçuluğu yapan üreticilerin ticari üretim için gelir seviyelerinin de yetersiz olduğu dikkate alınmalıdır (İnci ve ark., 2015).

Araştırmanın yürütüldüğü dönem ve sonrasında ilde etlik piliç üretim entegrasyonu olmamasına rağmen TKDK (Tarımsal Kalkınmayı Destekleme Kurumu) destekli olarak 1 adet etlik piliç işletmesinde 5 adet kümes (44.000, $55.000, \quad 55.000, \quad 60.000,60.000$ piliç kapasiteli) kurulmuştur. Bunun yanında son yıllarda (2014 ve 2016) 30.000 ve 50.000 adet tavuk kapasiteli olarak kurulan iki ayrı yumurtacı işletmede üretim sürdürmektedir. $\mathrm{Bu}$ kümesler ve işletmelere ait özellikler yukarıda belirtilen küçük çaplı aile işletmelerden farklı, tamamen ticari 
amaçlarla kurulmuş işletmelerdir. Özellikle destek almak amaciyla projelendirilen kümesler modern alet ve ekipmanlarla donatılmış, çevre kontrollü kümeslerdir. Yumurta üretimi ise geleneksel kafes sisteminde gerçekleştirilmektedir. Etlik piliç üretimi amaciyla kurulan işletmede il dıșından civciv temin edip, (Ankara, Çankırı vb.) piliçleri kesim için il dışına göndermek suretiyle üretim yapıldığı ancak, mevcut kümes kapasite yetersizliğinden dolayı zaman içerisinde başka illerdeki entegre firmalarla çalışma imkanı bulamadığı için yumurta üretimine dönmüștür. Günümüzde bunlara ilave edilen işletme ve kümeslerle birlikte ticari yumurta üreten işletme sayıs1 14'e yükselmiştir. Bu kümeslerden 8 tanesi kısmen küçük kapasiteli (1500-4000 tavuk) serbest gezinmeli üretim sistemine sahip kümeslerdir. $\mathrm{Bu}$ işletmelerde üretilen yumurtalar il genelinde ve çevre illerde pazarlanabilmektedir. Yem alımları yerel veya çevre illerdeki fabrikalardan temin edilmektedir. Ticari işletmeler ülke genelindeki yapısal ve teknik özelliklere sahiptir ve işletmecileri de diğer üreticilere göre yeni arayışlar peşindedir. $\mathrm{Bu}$ açıdan diğer birçok çalışmada ortaya koyulan ticari işletme özelliklerini taşımakta, ürünleri ambalajlı, etiketli ve sınıflandırılmış olarak pazarlanmaktadır (Aydın ve Çelen, 2017; Çimrin ve ark., 2019; Efil ve Sarıca, 1994; Vaarst ve ark., 2015).

Kastamonu ilinde tavukçuluk büyük oranda geleneksel köy tavukçuluğu şeklinde ve aile içi tüketimin ön planda olduğu bir sistemde gerçekleşmektedir. $\mathrm{Bu}$ sistemde ekonomik bir amaç olmadığı için üreticilerin beklentileri de son derece düşüktür. Mevcut ișletmelerde sağlık riskleri ve diğer üretim faaliyetlerine alışkanlıklar ticari tavuk üretimine geçiş isteğini ve imkânını oldukça sinırlandırmaktadır.

Son yıllarda TKDK destekli kurulan bir etlik piliç üretim işletmesi ilde bir entegre kuruluşun olmaması nedeniyle ticari boyutta bir üretim gerçekleştirilememiştir. Ticari yumurta üretim işletmelerinin de bazı sorunları olmasına rağmen yumurta pazarlaması il içi ve çevre illere yapılabilmektedir. Özellikle köy tavukçuluğu olarak ifade edilen ve tüketiciler arasında doğal ürün olarak algılanan bu sistemin kontrolsüz olarak devam ettirilmesi halinde her türlü atığa ulaşabilen tavukların ürünlerinden kaynaklanabilecek olumsuzluklar dikkate alınmak zorundadır. $\mathrm{Bu}$ nedenle bu üretimin sürdürülmesi için küçük kapalı alanları olan, gezinme alanları çevrilmiş, hayvanların deterjan, ilaç, fosseptik çukurları, her türlü kimyasal ilaç, petrol ve yağ gibi kalıntılara ulaşmalarının engellenmesi sağlanmalıdır.

\section{Kaynaklar}

Aksoy, T., Yurt, Z., İlaslan, Ç.D., Yapıcı, N., 2007. Dünyada ve ülkemizde köy tavukçuluğu. 5. Ulusal Zootekni Bilim Kongresi, 56.

Aydın, F., Çelen, M.F., 2017. GAP bölgesi yumurta tavukçuluğu işletmelerinin demografik ve sosyo-ekonomik yapısı. Batman Üniversitesi, Journal of Life Sci., 7(3): 107-117.

Anonim a., 2020. Beyaz Et Sanayicileri Damızlıkçılar Birliği Derneği, www.besd-bir.org.

Anonim b., 2020. Yumurta Üreticileri Birliği, www.yum-bir.org. Çimrin, T., Parlakay, O., Çopur Akpınar, G., Tapkı, N., Yıldırım, H., 2019. Yumurta tavukçuluğu işletmeleri: Hatay ili örneği. KSÜ Tarım ve Doğa Bilimleri Dergisi, 22(5): 787-793.
Demirulus, H., 2001. Doğu Anadolu Tavukçuluğunun Sorunları Üzerine Bir Araştırma. I. Doğu Anadolu Kanatlı Yetiştiriciliği Sempozyumu, Yüzüncü Y1l Üniversitesi, 21-24 Mayıs, Van.

Efil, H., Sarıca, M., 1994. Çorum yöresi tavukçuluk işletmelerinin yapısal özellikleri, ekonomik durumları, sorunları ve çözüm yollarının araştırılması. Tr. J. Vet. and Anim. Sci., 307-314.

Eleroğlu, H., Yıldırım, A., Şekeroğlu, A., 2014. Sivas ili agroekolojik bölgelerinde köy tavukçuluğunun yapısı. Tavukçuluk Araştırma Dergisi, 11(2): 10-15.

Fajemilehin, S.O.K., 2010. Morhosptructural characteristics of three varieties of greybreasted helmeted guinea fowls in Nigeria. International Journal of Morphology, 28: 557-562.

Güngördü, S., Çelen, M.F., 2018. Batman ili köy tavukçuluğunun durumu. Batman Univ., Journal of Life Sci., 8(2): 3759.

İnci, H., Bural, R., Şengül, T., 2015. Bingöl ili köy tavukçuluğunun yapısı. Tavukçuluk Araştırma Dergisi, 12(2): 13-17.

İnci, H., Ekinci, M.A., Karakaya, E., Söğüt, B., Ayaşan, T., 2018. Diyarbakır ili köy tavukçuluğunun yapısı. Tavukçuluk Araştırma Dergisi, 15(2): 23-27.

Jha, B.K., Chakrabarti, A., 2017. Back yard poultry farming as a source of likelihood in tribal village: An economic appraisal. International J. Agric. Sci. and Res., 7(1): 267-274.

Köse, B., Durmuş, İ., 2014. Ordu ilindeki tavukçuluk işletmelerinin genel yapısı, sorunları ve çözüm önerileri. Akademik Ziraat Dergisi, 3(2): 89-94.

Nkukwana, T.T., 2018. Global poultry production: Current impact and future outlook on the South African poultry industry. South African J. Anim. Sci., 48(5): 869-884.

Rimi, N.A., Sultana, R., Ishtiak-Ahmed, K., Rahman, M.Z., Hasin, M., Islam, M.S., Aziz-Baumgartner, E., Nahar, N., Gurley, E.S., Puby, S.P., 2016. Understanding the faillure of behavior change intervention to reduce risk behaviors for avian influenza transmission among backyard poultry raisers in rural Bangladesh: A focused etnography. BMC Public Health, 16: 858.

Sarıca, M., Türkoğlu, M., Yamak, U.S., 2018a. Tavukçuluktaki gelişmeler ve Türkiye tavukçuluğu. Tavukçuluk Bilimi, Yetiştirme, Besleme, Hastalıklar (Editörler M.Türkoğlu, M.Sarıca),1-36, 5. Bask1 Bey Ofset, Ankara.

Sarıca, M., Erensoy, K., Özsoy, A., 2018b. Comparison of Embryo Development and Quality Characteristics of Uncontrolled Village Eggs and Commercial Eggs Produced in Different Seasons. International Poultry Science Cogress of WPSA Turkish Branch'2018, Niğde Ömer Halisdemir University, 912 May, Niğde, Congress Book, 140-144. (Sunulu Bildiri).

Sarıca, M., Erensoy, K., Yamak,U.S., 2019. The importance of sustanability poultry meat production in Turkey. International Agricultural Congress of Muş Province, 24-27 September, Proceedings Book, 175-183.

Sheldon, B.L., 2000. Research and development in 2000: Directions and priorities for the world's poultry science community. Poultry Sci., 79(2): 147-158.

Şahin, A., Yıldırım, İ., 2001. Van ilinde yumurta tavukçuluğu yapan işletmelerin ekonomik analizi. YYÜ Ziraat Fakültesi Tarım Bilimleri Dergisi, 11(2): 57-66.

Şekeroğlu, A., Akşimşek, Ş.D., 2009. Tokat ili köy tavukçuluğunun bazı özellikleri. Anadolu Tarım Bilimleri Dergisi, 24(2): 108-113.

Şekeroğlu, A., Sarı, H., Sarıca, M., Yıldırım, A., Duman, M., 2013. Effects of distance from the roadway on heavy metal content and egg quality of village laying hen's egg along roadsides of Tokat-Turhal, Turkey. Pak. J. Agri. Sci., 50(2): 299-304.

Şekeroğlu, A., Sarıca, M., 2010. Bir üretim sistemi olarak köy tavukçuluğu. Tavukçuluk Araștırma Dergisi, 9(1): 41-47.

Türkoğlu, M., Eleroğlu, H., 1999. Serbest broiler yetiştiriciliği. VIV Poultry Yutav' 99, Uluslararası Tavukçuluk Fuarı ve Konferans1, 3-6 Haziran, İstanbul, Bildiriler 110-122, İstanbul.

Vaarst, M., Steenfeldt, S., Horsted, K., 2015. Sustainable development perspectives of poultry production. World Poult Sci.J., 71: 609-620. 